\title{
End criminal sanctions for abortion
}

\author{
Richard Hurley features and debates editor
}

The BMJ

The 1967 Abortion Act entitled British women to a legal termination of pregnancy, provided that certain conditions were met. It created exemptions to the 1861 Offences Against the Person Act, which is still on the statute books and makes abortion a crime punishable by life in prison.

Calls for legal reform are gathering momentum, as Sally Howard reports (doi:10.1136/bmj.j5278). Critics claim that the law is out of step with public attitudes, hinders evidence based clinical practice, and stigmatises procedures that a third of UK women will choose at some point in their lives. Two women were recently imprisoned in England for not meeting the 1967 act's requirements, and the act does not apply in Northern Ireland (doi:10.1136/bmj.j1485).

In September the Royal College of Obstetricians and Gynaecologists voted for an end to criminal sanctions for abortion, saying that procedures should be considered similar to other healthcare interventions, by adhering to professional, regulatory, and legal standards, while retaining gestational limits. The BMA's annual representative meeting in June voted in favour of a similar motion. In March a private member's bill to decriminalise abortion up to 24 weeks' gestation passed its first reading in parliament (doi:10.1136/bmj.j1485).

The BMJ supports these calls for decriminalisation. Polls show that more than two thirds of the public support women's right to choose abortion on demand. ${ }^{12}$ But the 1967 act restricts access by permitting abortion only if two doctors agree that continuing the pregnancy would be detrimental to the woman's mental health. The act also requires all abortions, including medical abortion in early pregnancy, to be performed only by doctors in certain registered premises. So, buying mifepristone online and taking it to induce an abortion at home is an offence.

Many European countries allow early abortion on demand, including France and Germany. Canada abolished its abortion law nearly 30 years ago, without any increase in incidence (doi:10.1136/bmj.j1506). Some Australian states have removed abortion from the criminal statute.

Of course, termination of pregnancy is a particularly sensitive and ethically controversial matter, in which an individual's conscience must lead. Sandy Goldbeck-Wood, a gynaecologist and editor of BMJ Sexual and Reproductive Health, recognises this in her thoughtful essay about the emotional demands of her practice (doi:10.1136/bmj.j5275).

She emphasises the importance of providing space for conversation between patient and practitioner and for conscientious reflection, with the aim of fostering "greater resolution and integration, a better chance that a woman, whatever her decision, will be able to "move on." But, she adds, the discussion also protects the surgeon.

NatCen. British attitudes to abortion. Aug 2017. www.natcen.ac.uk/blog/british-attitudesto-abortion.

2 We Trust Women. 5 reasons to decriminalise abortion. www.wetrustwomen.org.uk/5reasons-to-decriminalise-abortion.

Published by the BMJ Publishing Group Limited. For permission to use (where not already granted under a licence) please go to http://group.bmj.com/group/rights-licensing/ permissions 